\title{
Penerapan Pendidikan Karakter di Era Digital Melalui Kegiatan Bazar Bulanan (Monthly Bazaar)
}

\author{
Zakiyah Ismuwardani ${ }^{1}$, Sri Hastuti ${ }^{2}$ \\ ${ }^{1,2}$ Pendidikan Guru Sekolah Dasar, Fakultas Keguruan Ilmu Pendidikan, Universitas Nahdhlatul \\ Ulama Cirebon \\ Zakiyahismuwardani773@gmail.com
}

\begin{abstract}
ABSTRAK
Penelitian ini bertujuan untuk menjadikan peserta didik memiliki karakter mandiri, disiplin dan tanggung jawab di era digital melalui kegiatan Bazar Bulanan (Monthly Bazaar). Metode yang digunakan dalam penelitian ini adalah Mixed Method dengan strategi eksploratoris sekuensial. Strategi eksploratoris sekuensial melibatkan pengumpulan dan analisis data kuantitatif pada tahap kedua yang didasarkan pada hasil-hasil tahap pertama. Bobot/ priorotas lebih cenderung pada tahap pertama, dan proses pencapuran antar kedua metode ini terjadi ketika peneliti menghubungkan antara analisis data kualitatif dan pengumpulan data kuantitatif. Hasil penelitian didapat dari analisis data kualitatif pada tahap pertama dan kuantitatif pada tahap kedua. Hasil tahap pertama didapatkan dari pengamatan pendidik terhadap peserta didik setelah selesai pelaksanaan bazar bulanan. Hasil tahap kedua didapatkan melalui penghitungan menggunakan Skala Likert dan diperoleh angka 43,75\% (pernah) jika dikategorikan dalam kriteria interpretasi skor berdasarkan interval. Angka tersebuat didapat sebelum dilaksanakannya kegiatan bazar bulanan. Setelah dilaksanakan bazar bulanan sebanyak dua kali didapat angka $72,75 \%$ (sering). Dari kedua tahap tersebuat didapatkan hasil yang relevan antara analisis data kualitatif dan kuantitatif bahwa adanya karakter mandiri, disiplin dan tanggungjawab yang tertanam pada peserta didik setelah dilaksanakannya kegiatan bazar bulanan.
\end{abstract}

Kata kunci: Pendidikan Karakter, Era Digital, Bazar Bulanan

\section{ABSTRACT}

This study aims to make students have an independent character, discipline and responsibility in the digital era through the Monthly Bazaar. The method used in this research was Mixed Method with a sequential exploratory strategy. The sequential exploratory strategy involves collecting and analyzing quantitative data in the second stage based on the results of the first stage. Weights / priorities are more likely to be in the first stage, and the mixing process between these two methods occurs when the researcher makes a connection between qualitative data analysis and quantitative data collection. The results of the study were obtained from qualitative data analysis in the first stage and quantitative data in the second stage. The results of the first stage were obtained from educators' observations of students after completing the monthly bazaar. The results of the second stage are obtained through calculations using a Likert scale and it is obtained the data of $43.75 \%$ (ever) if it is categorized in interpretation of scores based on intervals. This data was obtained before the implementation of the monthly bazaar. After implementing the monthly bazaar for two times, the data is $72.75 \%$ (often). From the two stages, the relevant results obtained between qualitative and quantitative data analysis showed that there was an independent character, discipline and responsibility embedded in students after the implementation of the monthly bazaar activities.

Keywords: Character Education, Digital Era, Monthly Bazaar

PENDAHULUAN
Pendidikan adalah suatu proses
perubahan sikap, penambahan ilmu
pengetahuan, dan pengalaman hidup agar siswa
mampu menjadi lebih baik dalam pemikiran

maupun sikap. Pendidikan di era digital saat ini sangatlah penting, kemajuan dalam bidang teknologi tidak hanya dinikmati oleh orang dewasa, tetapi anak-anak usia Sekolah Dasar saat ini sudah bisa menikmati hasil dari 
perkembangan teknologi. Teknologi banyak dimanfaatkan dalam dunia pendidikan, sebagai sarana dan prasarana interaksi antara pendidik dan peserta didik (Putri, 2018). Perkembangan teknologi saat ini mempunyai dampak positif serta dampak negatif, sebaiknya dampak positif lebih dominan dimanfaatkan oleh pengguna teknologi, daripada dampak negatif.

Pada era digital peran teknologi sangat diperlukan untuk menghadapai persaingan ditengah masyarakat (Liantoni et al., 2018). Dalam ruang lingkup pendidikan teknologi pun memiliki peran penting guna menopang segala kemajuan yang terjadi di lingkungan pendidikan. Dimana dalam proses pembelajaran di zaman sekarang sudah pasti mengikuti perkembangan teknologi. Maka dari itu sebagai seorang pendidik wajib untuk mengerti dan mengikuti segala perkembangan teknologi yang terjadi di tengah-tengah dunia pendidikan.

Dengan mengikuti perkembangan teknologi, diharapkan pendidik agar dapat selalu berinovasi dalam setiap kegiatan pembelajaran. Ketika kegiatan pembelajaran dilaksanakn dengan mengikuti perkembangan teknologi maka pembelajaran tersebut tak lepas dari kemajuan zaman dan tentunya akan terdapat kebaharuan dalam muatan pembelajaran tersebut. Pembelajaran yang efektif terlihat dari bagaimana pembelajaran tersebut dapat menjawab kebutuhan siswa, serta tuntutan kemajuan zaman (Purnasari \& Sadewo, 2020).

Adapun yang terjadi di lapangan khusunya di dalam lingkungan pendidikan, pengaruh negatif lebih dominan mengambil peran terhadap sikap peserta didik. Seperti sikap kurang mandiri, kurang disiplin, dan kurang bertanggungjawab. Kurang mandiri dapat dilihat dari terlalu mengandalkan internet dalam penyelesaian tugas tanpa melihat dan menyaring lagi apa yang di dapatnya melalui internet. Sehingga menjadikan peserta didik terlalu bergantung kepada internet, dan tidak mandiri dalam menyelesaaikan tugas. Karakter kurang disiplin dapat dilihat dari cara peserta didik dalam mematuhi segala perintah dan aturan yang diberlakukan oleh sekolah maupun pendidik di lingkungan sekolah. Dan karakter kurang tanggungjawab dapat dilihat dari cara peserta didik kurang mampu bertanggungjwab atas tugas yang diberikan kepada mereka saat proses belajar mengajar di dalam kelas, contoh kecilnya saat diberikan tugas kelompok beberapa peserta didik hanya duduk dan mengandalkan teman yang lainnya.
Melihat dari beberapa permasalahan yang ditemukan tentang beberapa karakter peserta didik di lingkungan Sekolah Dasar, peneliti berupaya untuk menerapkan kembali pendidikan karakter di era digital melalui kegiatan Bazar Bulanan. (Nurhayati, 2018) dalam penelitiannya mengemukakan bahwa kegiatan Bazar Bulanan akan melatih peserta didik untuk aktif, serta menjadikan peserta didik untuk tidak bergantung lagi kepada orang lain. Dengan melakukna kegiatan bazar bulanan melatih peserta didik untuk bertanggungjawab terhadap sesuau yang ia jual, sehingga menjadikannya lebih mandiri dan disiplin terhadap apa-apa yang harus mereka patuhi dan persiapkan sebelum malakukan proses jual beli dalam acara bazar tersebut.

Pendidikan karakter juga dapat didefinisikan sebagai segala usaha yang dapat dilakukan untuk mempengaruhi karakter siswa. Dijabarkan pada penelitian (Ridwan Santoso, 2018) bahwa Pendidikan karakter mengandung tiga unsur pokok, yaitu mengetahui kebaikan (knowing the good), mencintai kebaikan (loving the good), dan melakukan kebaikan (doing the good). Pendidikan karakter tidak hanya mengajarkan mana yang benar dan mana yang salah kepada peserta didik, tetapi lebih dari itu pendidikan karakter menanamkan kebiasaan (habituation) tentang sesuatu yang baik sehingga peserta didik paham, mampu merasakan, dan mau melakukan yang baik.

Berdasarkan penjelasan di atas, maka dapat diambil kesimpulan bahwa dalam mewujudkan pendidikan yang berkarakter adalah dengan mampu menanamkan nilai-nilai karakter kepada peserta didik sebagai fondasi agar terbentuknya generasi yang berkualitas yang mampu hidup mandiri dalam kehidupan sehari-hari. Sehingga nantinya bisa menjadi manusia yang memiliki prinsip suatu kebenaran yang dapat dipertanggungjawabkan. Sedangkan untuk karakter mandiri, disiplin dan tanggungjawab yang diharapkan dapat dimiliki oleh peserta didik nantinya dapat tercermin dalam beberapa kegiatan di sekolah maupun luar sekolah.

Tujuan pembentukan karakter adalah
untuk memfasilitasi penguatan dan pengembangan nilai-nilai tertentu sehingga terwujud dalam perilaku peserta didik, baik ketika proses belajar di sekolah maupun setelah lulus sekolah. Mengoreksi perilaku peserta didik yang tidak sesuai dengan nilai-nilai yang ditanamkan di sekolah, dan membangun hubungan yang harmoni dengan keluarga dan masyarakat dalam memerankan tanggungjawab 
pendidikan karakter secara bersama (Wahyuni \& Hidayati, 2017).

Kemandirian belajar merupakan keharusan dalam proses pembelajaran di era digital, dimana pelajaran itu diarahkan untuk masa depan peserta didik, yang dengan nyata dapat dilihat dalam keluarga dan masyarakat. Menbentuk sikap mandiri bukan hal yang mudah, namum perlu suatu proses latihan yan panjang. Dalam penelitian (Nalindra et al., 2013) menyebutkan bahwa melalui proses pembelajaran di sekolah diharapkan mampu untuk menamankan karakter mandiri bagi peserta didik. Sekolah bukan hanya berfungsi sebagai transfer of knowlage, melainkan juga pembentukan sikap dan karakter peserta didik, seperti penanaman kemandirian dan karakter positif lainya.

Disiplin adalah kepatuhan untuk menghormati dan melaksanakan suatu sitem yang mengharuskan orang untuk tunduk pada keputusan, perintah atau peraturan yang berlaku. Dengan kata lain disiplin adalah kepatuhan menaati peraturan dan ketentuan yang telah ditetapkan. Disiplin hakikatnya adalah pernyataan sikap mental individu maupun masyarakat yang mencerminkan rasa ketaatan, kepatuhan, yang didukung oleh kesadaran untuk menunaikan tugas dan kewajiban dalam rangka pencapaian tujuan yang sudah ditetapkan (Patmawati, 2018). Karakter disiplin di sekolah berarti peserta didik memiliki sikap patuh ataupun patuh terhadap aturan sekolah guna tercapainya visi misi yang sudah ditetapkan oleh pihak sekolah.

Tanggungjawab adalah kesadaran manusia akan tingkah laku atau perbuatan yang disengaja maupun yang tidak di sengaja. Sejalan dengan pemaparan sebelumnya, Ridwan Santoso (2018) dalam penelitiannya menjelaskan bahwa tanggungjawab juga berarti berbuat sebagai perwujudan kesadaran akan kewajibannya. Tanggungjawab itu bersifat kodrati, yang berarti sudah menjadi bagian kehidupan manusia, bahwa setiap manusia pasti dibebani dengan tanggung jawab. Karakter tanggungjawab di sekolah dapat tercermin dalam beberapa prilaku seperti peserta didik mengerjakan tugas sesuai arahan pendidik.

Penerapan karakter mandiri, disiplin dan tanggungjawab di era digital tidak lepas dari dampak negatif, untuk itu sebagai pendidik harus mengawasi peserta didik dalam memanfaatkan teknologi. Keluarga sebagai orang terdekat peserta didik, juga memiliki peran penting dalam mengawasi dan membimbing peserta didik dalam memanfaatkan teknologi (Novantiyah, 2012). Keluarga juga berhak mengawasi si anak dalam bergaul dengan siapa di lingkungan sekitar. Sedangkan untuk tanggungjawab di sekolah pendidiklah yang memegang peran penting dalam penerapan karakter mandiri, disiplin, dan tanggungjawab peserta didik di era digital.

Menurut Afandi (2013) bazar merupakan salah satu pendidikan yang bertujuan memberikan pemahaman dan kesadaran yang relatif lebih utuh tentang kehidupan, membentuk struktur emosi dan mentalitas yang lebih stabil, serta membangun sikap-sikap keseharian yang lebih tercerahkan dari waktu ke waktu. Bazar merupakan aktifitas pembelajaran kewirausahaan, dimana peserta didik diajarkan bagaimana memasarkan produk kepada teman, pendidik ataupun kepada pihak luar. Kegiatan ini biasanya berbentuk pasar yang diselenggarakan di sekitar sekolah, dan kegiatan bazar biasanya melibatkan segenap komponen sekolah. Kegiatan bazar biasanya dilaksanakan tidak setiap hari melainkan pada waktu tertentu dengan tujuan tertentu.

Bazar bukan hanya mengajarkan tatacara berinteraksi jual beli pada peserta didik. Banyak nilai moril yang bisa ditanamkan kepada peserta didik, seperti kemandirian, kedisiplinan, kejujuran, tanggungjawab, komunikasi yang baik, dan beberapa karakter baik lainnya, serta menanamkan nilai-nilai syari'at Islam yang benar dalam kegiatan jual beli kepada peserta didik yang berhubungan erat dengan Pendidikan (Mayangsari, 2018). Bazar bulanan dalam penelitian ini dilaksanakn selama dua kali dalam dua bulan pada bulan juni dan juli. Alasan dilaksanakan bazar bulanan agar terdapat jeda untuk menganalisis hasil dari bazar pertama ke bazar selanjutnya, serta agar dapat melakukan beberapa evaluasi jika diperlukan agar tercapainya tujuan yang diharapkan.

Agar tercapainya pendidikan karakter yang di harapkan (mandiri, disiplin, dan tanggungjawab), yang termasuk dalam 18 karakter yang harus dimiliki oleh peserta didik yang terdapat dalam Pendidikan Nasional. Maka diperlukan usaha lebih agar krisis karakter pada peserta didik yang terjadi di lingkungan sekolah dapat teratasi dan diperbaiki. Adapun usaha yang dilakukan agar tercapainya karakter yang diharapkan adalah dengan melalui kegiatan bazar bulanan, dimana melalui kegiatan tersebut dapat melatih karaker mandiri, disiplin dan tanggungjawab peserta didik. Dalam kegiatan bazar bulanan tersebut terdapat aturan yang harus dipatuhi selama 
kegiatan berlangsung, aturan-aturan tersebut dapat diterapkan guna melatih karakter mandiri, disiplin, dan tanggungjawab peserta didik.

Diharapkan setelah dilakukannya kegiatan bazar bulanan peserta didik terbiasa dalam penerapan karakter (mandiri, disiplin, dan tanggungjawab) dalam keseharian terutama jika di terapkan dalam kegiata belajar mengajar di sekolah. Selain itu dalam pnelitian yang dilakukan oleh Benninga et al., (2003) dalam penelitiannya menyebutkan bahwa penerapan karakter yang baik pada peserta didik dapat memeberikan efek yang positif terhadap pencapaian akademik peserta didik. Dari penelitian tersebut maka dapat diketahui bahwa pendidikan karakter tidak hanya dapat memebrikan perubahan sikap positif pada peserta didik melainkan dapat memeberikan efek yang baik pula pada pencapaian akademik peserta didik.

\section{METODE PENELITIAN}

Metode penelitian yang digunakan dalam penelitian ini ini adalah Mixed Method dengan strategi ekploratoris sekuensial. Stategi Eksploratoris Sekuensial menurut Creswell (2014) melibatkan pengumpulan dan analisis data kualitatif pada tahap pertama, yang kemudian diikuti oleh pengumpulan dan analisis data kuantitatif pada tahap kedua yang didasarkan pada hasil-hasil tahap pertama. Bobot/ priorotas lebih cenderung pada tahap pertama, dan proses pencapuran antar kedua metode ini terjadi ketika peneliti menghubungkan antara analisis data kualitatif dan pengumpulan data kuantitatif.

Penelitian dilaksanakan di SDN 4 Sigong, salah satu Sekolah Dasar yang terdapat di Kabupaten Cirebon. Objek dalam penelitian ini adalah pendidikan karakter, era digital dan bazar bulanan. Terdapat tiga karakter yang menjadi fokus dalam penelitian ini yaitu karakter mandiri, disiplin dan tanggungjawab. Adapun sample dalam penelitian ini adalah 100 peserta didik dari kelas atas yang diambil secara random. Dalam penelitian ini peneliti akan mencoba menerapkan pendidikan karakter (mandiri, disiplin dan tanggungjawab) di era digital melaui kegiatan bazar bulanan.

\section{HASIL \& PEMBAHASAN}

Peneliti mengumpulkan data mengenai penanaman karakter mandiri, disiplin dan tanggungjawab melalui analisis data kualitatif dan kuantitatif, yaitu menggunakan wawancara dan penghitungan angket tentang pendidikan karakter menggunakan skala likert. Wawancara dilakukan pada tahap awal penelitian ini, kemudian diikuti oleh penghitungan skala likert pada tahap kedua. Hasil wawancara dilakukan pertama di awal observasi sebelum dilaksanakan penelitian. Wawancara awal diberikan kepada kepala sekolah serta para pendidik SDN 4 Sigong.

Hal-hal yang ditanyakan di awal wawancara adalah tentang tiga karakter yang menjadi fokus dalam penelitian yaitu karakter mandiri, disiplin dan tanggungjawab. Peneliti juga bertanya tentang sejauh mana pencapaian tentang kegiatan PPK (Penguatan Pendidikan Karakter) yang sebelumnya sudah menjadi program Pemerintah.

Hasil dari wawancara pertama didapatkan bahwa kurangnya persiapan dalam penerapan kegiatan Penguatan Pendidikan Karakter tersebut, karena tidak adanya indikator yang menjadi tolak ukur ketercapaian karakter yang diharapkan. Tidak adanya indikator dalam mencapai karakter yang diharapkan menjadikan para pendidik kurang fokus dalam menerapkan Penguatan Pendidikan Karakter pada peserta didik. Sehingga diperlukan indikator dalam mencapai beberapa karakter yang diharapkan.

Setelah dilakukannya wawancara pertama di awal observasi peneliti membagikan angket yang sudah dibuat. Adapun angket berisikan tentang tiga pendidikan karakter yang menjadi fokus dalam penelitian. Tujuan dari pemberian angket tentang pendidikan karakter adalah agar peneliti mudah melakukan penilaian sejauh mana karakter yang diharapkan telah dicapai, selain dari hasil wawancara yang dilakukan pada kepala sekolah dan para pendidik.

Penyebaran angket tentang pendidikan karakter dilakukan sebanyak tiga kali. Angket pertama diberikan sebelum pelaksanaan bazar bulanan guna mengetahui sejauh mana peserta didik memiliki karakter mandiri, disiplin dan tanggungjawab. Angket kedua diberikan setelah pelaksanaan bazar bulanan pertama pada bulan juni, tujuannya adalah untuk mengetahui sejauh mana bazar bulanan pertama memberikan pengaruh terhadap karakter mandiri, disiplin dan tanggungjawab peserta didik. Angket ketiga diberikan setelah dilaksanakannya bazar bulanan yang terkahir, adapun tujuan dari diberikannya angket yang ketiga adalah untuk mengukur sejauh mana kegiatan bazar bulanan memberikan pengaruh terhadap karakter mandiri, disiplin dan tanggungjawab peserta didik di era digital. 
Rumus yang digunakan dalam menghitung angket tentang pendidikan karakter menggunakan rumus index $\%$.

$$
\text { Index } \%=\frac{\text { Total Skor }}{\mathrm{Y} \times 100}
$$

Dari rumus diatas, niali $\mathrm{Y}$ diperoleh melalui penjumlahan dari skor tertinggi dikalikan jumlah responden. Dimana terdapat empat skor dalam angket pendidikan karakter $(1,2,3$ \& 4), dan jumlah responden dalam penelitian ini adalah 100, jadi skor tertinggi dikalikan 100 hasilnya 400, maka nilai Y dalam rumus index \% adalah 400 .
Setelah dihitung menggunakan rumus index \%, pertama-tama peneliti perlu mengetahui rentang jarak (interval) dalam penghitungannya, sehingga mampu menginterpretasikan hasil setiap penghitungan menggunakan rumus index \%. Rentang jarak yang didapat dalam penghitungan menggunakan rumus interval adalah 25 , didapat dari total responden dibagi jumlah skor angket. Berikut adalah kriteria interpretasi skor berdasarkan interval:

Tabel 1.

Kriteria Interpretasi skor berdasarkan interval

\begin{tabular}{lll}
\hline Persentase (\%) & Interval & Kategori \\
\hline $0 \%-24,99 \%$ & 25 & Tidak Pernah \\
$25 \%-49,99 \%$ & 25 & Pernah \\
$50 \%-74,99 \%$ & 25 & Sering \\
$75 \%-100 \%$ & 25 & Selalu \\
& & \\
\hline
\end{tabular}

Mengacu kepada kriteria interpretasi skor berdasarkan interval yang telah dibuat. Dari hasil angket pendidikan karakter yang diberikan pertama kali sebelum dilaksanakannya kegiatan bazar bulanan, didapat hasil $43,75 \%$ dalam penghitungan yang menggunakan rumus index \%. Jika dikategorikan dalam kriteria interpretasi skor berdasarkan interval, nilai tersebuat masuk dalam kriteria "pernah". Berdasarkan hasil yang didapat dari pembagian angket pertama berarti peserta didik pernah melakukan beberapa kegiatan yang mengandung karakter mandiri, disiplin dan tanggungjawab dalam beberapa kegiatan di sekolah.

Pada bulan Juni bazar bulanan pertama kali dilaksanakan. Peserta didik sangat antusias melaksanakan kegiatan tersebut. Tata tertib pelaksanaan bazarpun sudah disampaikan baik kepada peserta didik maupun pendidik. Setelah bazar selesai dilaksanakan peneliti melakukan analisis dan evaluasi dengan membagikan angket pendidikan karakter untuk kedua kali. Dari sebaran angket pendidikan karakter yang kedua diperoleh hasil $64,50 \%$ yang memiliki kriteria "sering".

Setelah melakukan analisis terhadap pelaksanaan bazar pertama, bazar kedua dilaksanakan di bulan Juli dengan beberapa pembaharuan. Angket pendidikan karakter dibagikan pula setelah selesai dilaksanakannya bazar kedua. Di dapatkan hasil 72,75\% untuk hasil dari analisis angket pendidikan karakter yang ketiga. Hasil tersebut masuk dalam kriteria "sering" yang berarti karakter mandiri, disiplin dan mandiri sudah dilaksanakan dengan sering oleh peserta didik setelah dilaksanakannya kegiatan bazar bulanan.

Berikut grafik tentang penerapan pendidikan karakter di era digital melalui kegiatan bazar bulanan yang dilakasnakan sebanyak dua kali bazar selama dua bulan. Karakter yang difokuskan adalah karakter mandiri, disiplin dan tanggungjawab. 


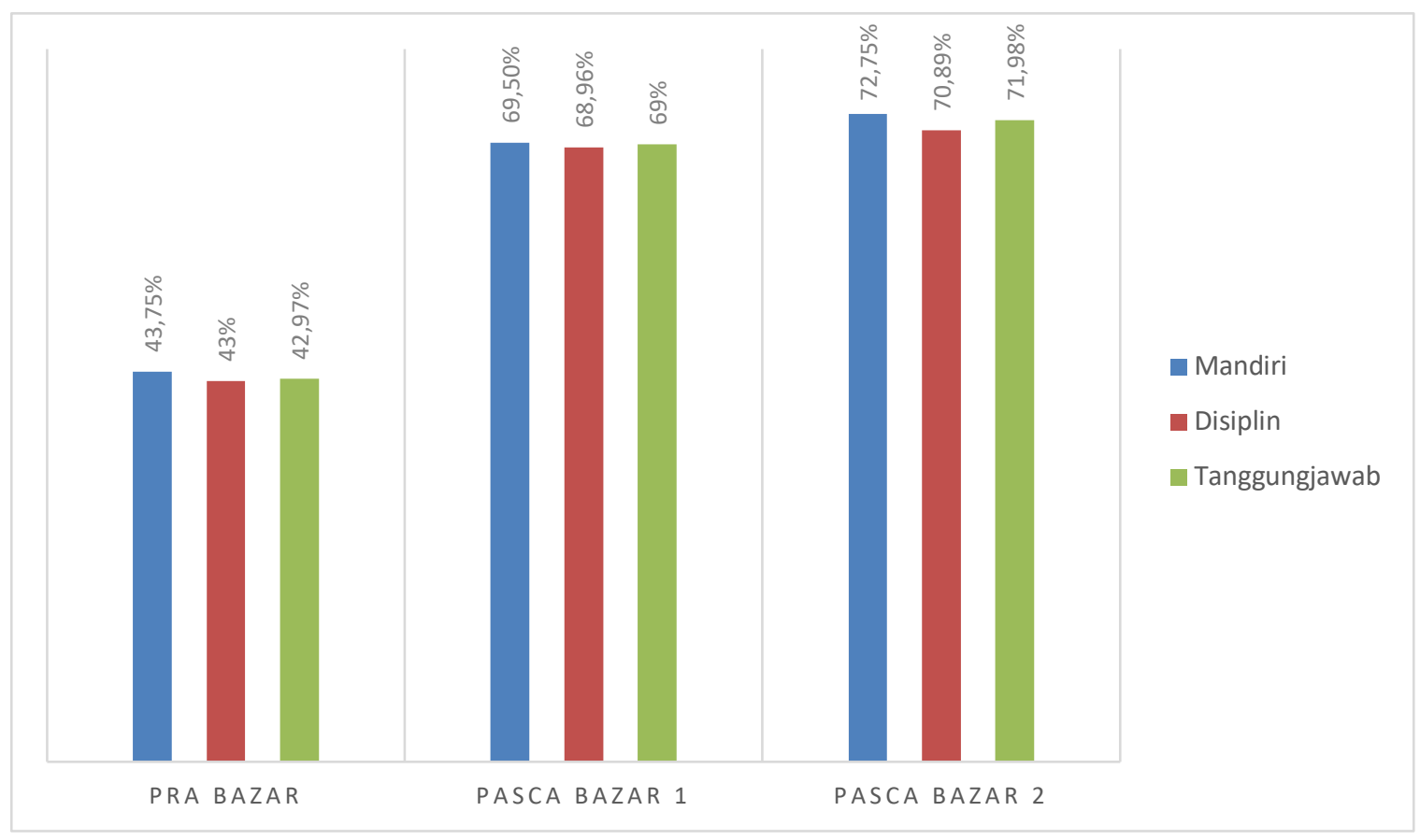

Gambar 1.

Gravik kemajuan Penerapan Karakter melalui kegiatan Bazar Bulanan

Dari gravik diatas dapat dijelaskan bahwa karakter mandiri, disiplin dan tanggungjawab yang diterapkan pada peserta didik di era digital melalui kegiatan bazar bulanan mengalami peningkatan. Peningkatan tersebut dapat dilihat dari meningkatnya gravik yang dapat dilihat pada gambar 1. Adapun peningkatan di dapat dari hasil penghitungan angket.

Angket pertama diberikan saat bazar belum pernah dilaksanakan. Dari angket pertama didapatkan hasil untuk karakter mandiri $43,75 \%$, untuk disiplin $43 \%$ dan untuk tanggungjawab $42,97 \%$. Ketiga hasil tersebuat jika dikategorikan masuk dalam kriteria "pernah", yang berarti peserta didik pernah melakukan beberapa kegiatan yang mengandung unsur karakter mandiri, disiplin dan tanggungjawab dalam beberapa kegiatan di sekolah.

Bazar pertama dilaksanakan pada tanggal 15 juni 2020, dan angket pendidikan karakter di bagikan setelah selesai kegiatan bazar. Dari angket kedua didapatkan hasil untuk mandiri $69,50 \%$, untuk disiplin $68,98 \%$ dan untuk tanggungjawab 69\%. Jika dikategorikan dalam kriteria interpretasi skor berdasarkan interval memiliki arti sering. Berarti peserta didik sering melakukan kegiatan-kegiatan yang mengandung unsur karakter mandiri, disiplin dan tanggungjawab dalam beberapa kegiatan di sekolah.
Angket terakhir diberikan di bulan juli setelah selesai pelaksanaan bazar kedua di tanggal 06 Juli 2020. Adapun untuk hasil yang diperoleh dari pembagian angket tentang pendidikan karakter tersebut adalah $72,75 \%$ untuk mandiri, 70,89\% untuk disiplin, dan $71,98 \%$ untuk tanggungjawab. Dari ketiga hasil tersebut semuanya masuk dalam kriteria sering, yang berarti peserta didik sering melakukan beberapa kegiatan di sekolah yang di dalam kegiatan tersebut mengandung unsur karakter mandiri, disiplin dan tanggungjawab.

Angket kedua dan ketiga memiliki kriteria yang sama yaitu sering namun berbeda dalam jumlah total skor. Berarti perbedaan kedua angket tersebut adalah meningkatnya kesadaran peserta didik bahwa karakter yang baik akan berdampak baik bagi diri mereka sendiri. Karakter mandiri, disiplin dan tanggungjawab yang peneliti coba terapkan melalui kegiatan bazar bulanan berdampak pada beberapa aktivitas dan perilaku peserta didik di sekolah.

Dari pembagian angket tentang pendidikan karakter tersebut peserta didik mengalami perubahan karakter yang baik setelah diterapkannya bazar bulanan. Kegiatan bazar bulanan memberikan dampak yang baik bagi karakter peserta didik diantaranya perubahan dalam sikap mandiri, yang mana karakter mandiri adalah karakter yang wajib dimiliki oleh peserta didik (Tannir \& Al-Hroub, 2013) terutama dalam proses belajar mengajar 
di kelas. Selain karakter mandiri terdapat beberapa karakter yang berhasil diterapkan dalam diri peserta didik adalah karakter disiplin dan tanggungjawab.

Berikut beberapa kegiatan yang biasa peserta didik kerjakan setelah dilaksanakannya kegiatan bazar bulanan, mengerjakan tugas tanpa menyontek pada teman, berani tampil di depan kelas tanpa di perintah pendidik, tidak melulu menggunakan internet dalam menyelesaikan tugas, berpakaian rapih dan lengkap, menghapus papan tulis jika sudah selesai pembelajaran, membuang sampah pada tempatnya, dan masih banyak lagi kegiatan peserta didik biasa dikerjakan yang mencerminkan karakter mandiri, disiplin dan tanggungjawab.

\section{KESIMPULAN \& SARAN}

Berdasarkan hasil penelitian yang dilakukan di SDN 4 Sigong, maka dapat disimpulkan bahwa terdapat perubahan yang signifikan dalam karakter peserta didik. Bazar bulanan dilaksanakan di Sekolah tersebut sebagai upaya yang dilakukan peneliti untuk menanamkan karakter mandiri, disiplin dan tanggungjawab. Bazar bulanan dilaksanakan dua kali dalam dua bulan, dan dari kedua pelaksanaan bazar tersebut terdapat perubahan yang baik terhadap karakter peserta didik. Angket pendidikan karakter dibagikan sebanyak tiga kali baik itu pra bazar maupun pasca bazar, dan hasil yang didapat dari penyebaran angket pra bazar adalah $43,75 \%$ (pernah), dan hasil yang didapat pada penyebaran pasca bazar adalah $72,75 \%$ (sering). Dari data kualitatif maupun data kuantitatif didapatkan hasil yang relevan atara keduanya. Data kualitatif didapat dari hasil wawancara yang dilakukan sebelum dan sesudah dilaksanakannya bazar bulanan terhadap penerapan pendidikan karakter. Dari wawancara didapatkan hasil yang berbeda pada saat wawancara sebelum dan sesudah dilaksanakannya bazar bulanan. Sedangkan data kuantitatif didapatkan dari penghitungan index \%. Dari kedua data tersebut diperoleh hasil yang signifikan, bahwa adanya perubahan yang positif pada karakter mandiri, disiplin dan tanggung jawab peserta didik. Maka dapat disimpulkan bahwa kegiatan bazar bulanan dapat membantu peserta didik dalam menerapkan pendidikan karakter dalam kegiatan keseharian di sekolah.

Pendidikan karakter merupakan sebuah pendidikan yang secara tidak sengaja diajarkan pada peserta didik tanpa melalui proses belajar mengajar di dalam kelas. Peneliti melaksanakan bazar bulanan sebagai jembatan dalam penerapan karakter mandiri, disiplin dan tanggungjawab. Peneliti memeberikan saran untuk pihak sekolah maupun peneiti yang lain. Bagi pihak sekolah peneliti memberikan saran agar melakukan upaya mempertahankan karakter yang sudah tertanam pada diri peserta didik. Sedangkan bagi peneliti lain yang akan melakukan penelitian pada bidang kajian yang sama agar memeberikan sentuhan baru dalam menanamkan serta memepertahankan karakter yang sudah tertanam pada peserta didik.

\section{UCAPAN TERIMAKASIH}

Peneliti mengucapkan terimakasih kepada Direktorat Riset dan Pengabdian Masyarakat Kementrian Riset dan Teknolog/ Badan Riset dan Inovasi Nasional sebagai Pemberi dana pada artikel ilmiah yang peneliti tulis.

\section{DAFTAR PUSTA}

Afandi, R. (2013). Penanaman Jiwa Kewirausahaan pada Siswa Sekolah Dasar. Jurnal Pemikiran Dan Penge, Bangan SD, 1(2), 10-19.

Benninga, J. S., Berkowitz, M. W., Kuehn, P., \& Smith, K. (2003). The Relation of Character Education Implementation and Academic Achievement in Elementary School. Journal of Research in Character Education, 1(1), 19-32.

Liantoni, F., Rosetya, S., Rizkiana, R., Farida, \& Hermanto, L. A. (2018). Peran Teknologi Informasi Untuk Peningkatan Kemampuan Siswa SMA dan SMK Dalam Menghadapi Perkembangan Era Digital. Jurnal Publikasi Pendidikan, 8(2), 109-113.

Mayangsari, S. N. (2018). Do Elementary School Students Understand Entrepreneurial Values? Jurnal Pendidikan Dasar Islam (AULADUNA), 5(1), 64-75.

Nalindra, R., Latif, S., \& Utaminingsih, D. (2013). Meningkatkan Kemandirian Belajar siswa dengan menggunakan Layanan Konseling Kelompok. Jurnal Konseling FKIP Lampung, 1(3), 1-13.

Nurhayati, E. C. (2018). Pengaruh Market Day (Bazar) terhadap Membangun Jiwa Wirausaha Mahasiswa Unsiq Jawa Tengah di Wonosobo. Jurnal Paramurobi, 1(2), 1-16. 
Patmawati, S. (2018). Penerapan Pendidikan Karakter Disiplin dan Tanggungjawab siswa di SD Negeri No. 13/ 1 Muara Bulian. FKIP Universitas Jambi, 13, 116.

Purnasari, P. D., \& Sadewo, Y. D. (2020). Pemanfaatan Teknologi Dalam Pembelajaran Sebagai Upaya Peningkatan Kompetesnsi Pedagogik. Jurnal Publikasi Pendidikan, 10(3), 189-196.

Putri, D. P. (2018). Pendidikan Karakter Pada Anak Sekolah Dasar di Era Digital. Jurnal Pendidikan Dasar, 2(1), 37-49.

Ridwan Santoso, M. M. A. (2018). Inovasi Pendidikan Karakter melalui Pembelajaran Berbasis Lingkungan Sosial dan Budaya. Jurnal Sosial Dan Budaya, 1, 8.

Tannir, A., \& Al-Hroub, A. (2013). Effects of Character Education on the Self Esteem of Intellectually able and Less Able Elementary Students in Kuwait. International Journal of Special Education, 28(1), 47-59.

Wahyuni, W. R., \& Hidayati, W. (2017). Peran Sekolah dalam Membentuk Keterampilan Wirausaha Berbasis Tauhid di SD Entrepreneur Muslim Alif-A Piyungan Bantul Yogyakarta. Jurnal Manajemen Pendidikan Islam (MANAGERIA), 2(2), 359-377. 